\title{
Financial Restatement Period: Internal and External Auditing Mechanism
}

\author{
ELFINA ASTRELLA SAMBUAGA* \\ CHELSEA CHEN \\ JEANETTE YOVANKA \\ KRISTINA FRANSISKA \\ Universitas Pelita Harapan
}

\begin{abstract}
The purpose of this study is to empirically scrutinize the effects of audit quality, audit report lag, and audit committee characteristics on the length of financial restatements. The population analyzed in this study involved companies listed on the Indonesia Stock Exchange from 2016 to 2018. A purposive sampling technique was employed in this research, and the total sample was 153 observations. Multiple regression analysis indicates that audit quality, audit report lag, and audit committee characteristics are statistically significant toward the length of financial restatements. The audit committee characteristic and audit report lag compress the length of financial restatements, while the audit quality extends the length of financial restatements.
\end{abstract}

Keywords: restatement period, audit quality, audit report lag, audit committee characteristic

Abstrak-Tujuan dari penelitian ini adalah untuk mengkaji secara empiris pengaruh kualitas audit, audit report lag, dan karakteristik komite audit terhadap periode penyajian kembali laporan keuangan. Populasi yang diteliti dalam penelitian ini adalah perusahaan-perusahaan yang terdaftar di Bursa Efek Indonesia tahun 2016 hingga 2018. Teknik sampling yang digunakan adalah metode purposive sampling. Adapun sampel yang diambil berjumlah 153 observasi. Hasil penelitian melalui metode analisis regresi berganda menunjukkan bahwa kualitas audit, audit report lag, dan karakteristik komite audit memiliki pengaruh yang signifikan terhadap periode penyajian kembali laporan keuangan. Karakteristik komite audit dan audit report mempersingkat periode penyajian kembali laporan keuangan, sementara kualitas audit memperpanjang periode penyajian kembali laporan keuangan.

Kata Kunci: periode penyajian kembali laporan keuangan, kualitas audit, audit report lag, karakteristik komite audit 


\section{Introduction}

High-quality financial information is considered one of the essential keys to ensuring market efficiency (Zhizhong et al., 2011). The disclosure of such information will help the users allocate their resources effectively in the capital market. Therefore, financial statements as the primary source of information become a prominent element in firm information disclosures. Stakeholders often rely on the information provided in financial statements to forecast the prospect of a company, assess its market value, and make strategic decisions (Mao, 2018). However, the financial statements' information has not always been in following the qualitative characteristics of relevant financial information, particularly in the timeliness aspect. Several factors may contribute to this issue, including accounting estimation errors. Errors in accounting estimates may result in a lower quality of information, which subsequently requires the firm to restate its financial statement. Financial restatements are typically perceived as negative signals by investors as restatements may indicate the distortion, unreliability, and relatively lower quality of the preliminary financial information. This cause could lead to a significant decline in the firm's stock return, thus reducing its value (Mao, 2018; Pertami, 2016).

Aside from accounting estimation error and other forms of an accounting error, other factors that may contribute to financial restatements are related to the firm's business activities, for instance, merger and acquisition (GAO's Definition of Restatement, 2006). Higher accounting complexity signifies more time required to prepare, publish, and distribute the restated financial statements. To minimize the length of time required to prepare financial restatements, the role of internal and external auditing mechanisms should be equipped. In this context, external auditors are considered independent external monitors who will become the mediator to reduce asymmetric information between management and stakeholders. Accordingly, external auditors are obliged to adhere to the code of ethics in order to remain neutral. Another element that correlates with auditing is the audit report lag. Lengthy audit report lag indicates that the audit processes and procedures have been carried out with due care, 
which accelerates the detection of material misstatements in the corresponding period and decreases the possibility of misstatements in subsequent periods.

On the other hand, internal monitoring may be done by an audit committee, which is responsible for assuring the quality of financial reports. The audit committee chairman should possess financial and accounting expertise, for it is one of the crucial characteristics of an influential audit committee. With this expertise, the audit committee chairman is viewed as qualified in leading financial discussions and more effective in assigning duties to the audit committee members because he has more familiarity with the components of the financial statement. Consequently, he could lead to a shorter restatement period.

Several empirical studies by Francis et al. (2013), Rowe (2018), Zhizhong et al. (2011), Jiang et al. (2015), Lobo (2013), Kusuma and Rohman (2014), and Hasnan and Hussain (2015) found a significant negative association between audit quality and financial restatements. Meanwhile, the study of Rowe (2018) did not find relative evidence. Previous studies by Blankley et al. (2015) and Wei et al. (2017) concluded that the audit report lag in a corresponding period decreases the probability of subsequent restatements in the following year. Dezoort and Salterio (2001), Carcello et al. (2011), Cohen et al. (2013), and Shin et al. (2014) suggested that audit committees with expertise in finance and accounting are quicker in detecting any potential financial reporting issues as well as in communicating them. Nevertheless, Ali et al. (2017) pointed out that the audit committee's financial and accounting expertise may result in an extended length of financial restatements. This paper differs from previous studies because previous studies mostly focused on the factors contributing to the probability of financial restatements. Meanwhile, studies regarding the association of audit quality, audit report lag, and audit committee characteristics with financial restatements are relatively low, particularly in Indonesia studies.

A limited number of studies examine the correlation between audit quality, audit report lag, and audit committee characteristics with the length of financial restatements. This paper is mostly an extension of the study of Schmidt and Wilkins (2013), which investigated whether audit quality and audit committee expertise were associated with 
more timely restatement disclosures. The previous study was based on 154 observation samples in the United States which had financial restatements from 2004 to 2009.

Schmidt and Wilkins (2013) thus documented a significant positive relationship between audit quality and audit committee expertise toward the timeliness of restatement details provision.

This paper aims to scrutinize the impact of audit quality which is proxied by BigFour public accounting firm, audit report lag, and audit committee characteristic towards the length of financial restatements. Purposive sampling technique and multiple regression analysis have been applied in this research to obtain and examine samples from firms listed on the Indonesia Stock Exchange.

\section{Theoretical Framework and Hypothesis Development}

\subsection{Agency Theory}

Agency Theory is the theoretical perspective utilized in this research. Agency Theory emerges due to the nonalignment of interest between the firm owners (shareholders) as the principal and the executives managing the firm as the agent. The apparent asymmetric information faced by the principal and the agent magnifies the conflict of interest in both parties. Jensen and Meckling (1976) identified two underlying factors as the root of asymmetric information: Moral Hazard and Adverse Selection. These two factors require the presence of the role of auditors as the independent third party. They act as mediators in reducing the related agency cost and conflict of interest.

\subsection{Compliance Theory}

Lunenberg (2012) identifies Compliance Theory as an approach in organizations that integrate ideas and conceptions regarding certain matters through management participation. These ideas and conceptions are incorporated into the form of policies, often put together by authorized parties. Diverse motivations drive a firm to exhibit compliant behavior. These causal factors include the firm's stance in social norms, its efforts to avoid imposed legal sanctions, its pursuit for personal gain (Étienne, 2010). 
One of the fundamental regulations of public companies in Indonesia is from Financial Services Authority under Peraturan Otoritas Jasa Keuangan Nomor 29/POJK.04/2016, which regulates the filing of annual reports along with the related audit report for the period. Compliance with the regulation implies the firm's conformity to Otoritas Jasa Keuangan (OJK) under the Compliance Theory.

\subsection{Audit Quality and Restatement Period}

Audit quality is defined as a joint probability of two components; that the auditor (a) discovers a misstatement and (b) acts accordingly after the discovery. The former component is often associated with the auditor's capabilities, competence, and audit effort. On the other hand, the latter component measures the auditor's objectivity, professional skepticism, and independence (DeAngelo, 1981). Thus, the audit function is one of the monitoring devices to reduce information asymmetry that may cause misstatements and prompt a restatement (Arens et al., 2017).

Previous studies have consistently employed Big-Four accounting firms as the indicator of audit quality because Big-Four accounting firms are more likely to possess more capabilities and familiarity with the client's underlying accounting systems and business practices. Therefore, Big Four auditors are expected to carry out audits with more scrutiny and due care, thus compressing financial restatement periods. Previous studies of Schmidt and Wilkins (2013), Francis et al. (2013), Zhizhong et al. (2011), Jiang et al. (2015), Lobo (2013), and Kusuma and Rohman (2014) pointed out that high audit quality reduces restatements. However, the study of Rowe (2018) did not provide supportive evidence.

Hence, the hypothesis proposed in this study is that audit quality has a negative correlation with the restatement period. This hypothesis is based on the assumption that audit quality corresponds to the auditor's expertise in identifying potential material misstatement and consequently accelerates the auditor's response to address them appropriately.

H1: Audit quality is negatively associated with the restatement period. 


\subsection{Audit Report Lag and Restatement Period}

One of the important aspects to measure the quality of information is timeliness. Information should be accessible in time for users to exercise effective decisionmaking. In sum, timely audit reports equate to high audit duration quality. Audit report lag is commonly associated with audit risks encountered by auditors. Moreover, audit report lag also reflects audit effort involved in the practice. In other words, a shorter audit report lag implies that audit procedures may not be performed thoroughly. Bedrad and Johnstone (2004) noted that audit risks are related to audit hours and are important factors considered by auditors. When lengthy audit report lag occurs, it is assumed that the auditors conform with the applicable standard and consequently affect the quality of the financial statements. If more significant audit effort leads to higher audit quality, then it is expected to observe a negative correlation between audit report lag and the possibility of future restatements (Brankley et al., 2015). This finding is consistent with the study of Wei et al. (2017).

In this study, audit report lag is associated with higher audit quality, suggesting that auditors have applied appropriate audit procedures and professional due care. High audit effort means better audits performed following the applicable standard. As a result, the subsequent restatement period is more likely to decrease.

\section{H2: Audit report lag is negatively associated with the restatement period.}

\subsection{Audit Committee Characteristic and Restatement Period}

The audit committee characteristic focused in this study is the financial and accounting expertise of the audit committee. Following OJK regulation, at least one member of the audit committee shall be independent and has competence in finance and accounting. With the related expertise, the audit committee shall assist in the supervision of the financial reporting process effectively, thus reducing the restatement period to the minimum.

In line with the above-stated assumption, a prior study of Butar dan Sansaloni (2018) suggested that an audit committee with financial and accounting expert members reduces the likelihood of future restatements. The presence of significant financial and 
accounting expertise on the audit committee enhances its internal control, particularly in the control environment. As a result, misstatements are likely to decrease. Krishnan and Visvanathan (2008) also concluded similar results. However, Ali et al. (2017) pointed out a different conclusion.

Thus, this study's final hypothesis is that the audit committee characteristic reduces the financial restatement period. This hypothesis is based on the assumption that the audit committee's expertise in the related field equates to the comprehension of the financial reporting process and consequently minimizes the restatement period.

H3: Audit committee characteristic is negatively associated with the restatement period.

\section{RESEARCH METHOD}

\subsection{Sample and Data}

The samples in this study were collected from the companies listed on the Indonesia Stock Exchange from 2016 to 2018, which qualified the predetermined sampling criteria through the purposive sampling technique. This study comprises welldiversified samples across all industry sectors categorized on the Indonesia Stock Exchange. The criteria applied in this research included: (i) all companies listed on the Indonesia Stock Exchange between 2016 and 2018 that have been involved in financial restatements; (ii) restatement data that is presented in Rupiah (IDR); and (iii) restatement data that consists of the necessary information related to the variables studied.

A total of 150 firms had restated their annual financial statements during the 20162018 sample period, yet only 111 firms met the selection criteria. Among these 111 firms, 18 were set off by more than one trigger for financial restatements. Prior studies (Anderson and Yohn, 2002; and Dewi, 2014) treated these firms with separate observations. Therefore, this sample selection procedure yielded a total of 85 samples from the year 2016, 50 samples from the year 2017, and 48 samples from the year 2018, resulting in a final sample of 153 observations data in total. 


\subsection{Hypothesis Test}

Multiple linear regression model was applied in this study. The analysis of the effect of audit quality, audit committee, and audit report lag on restatement period is based on the following research model:

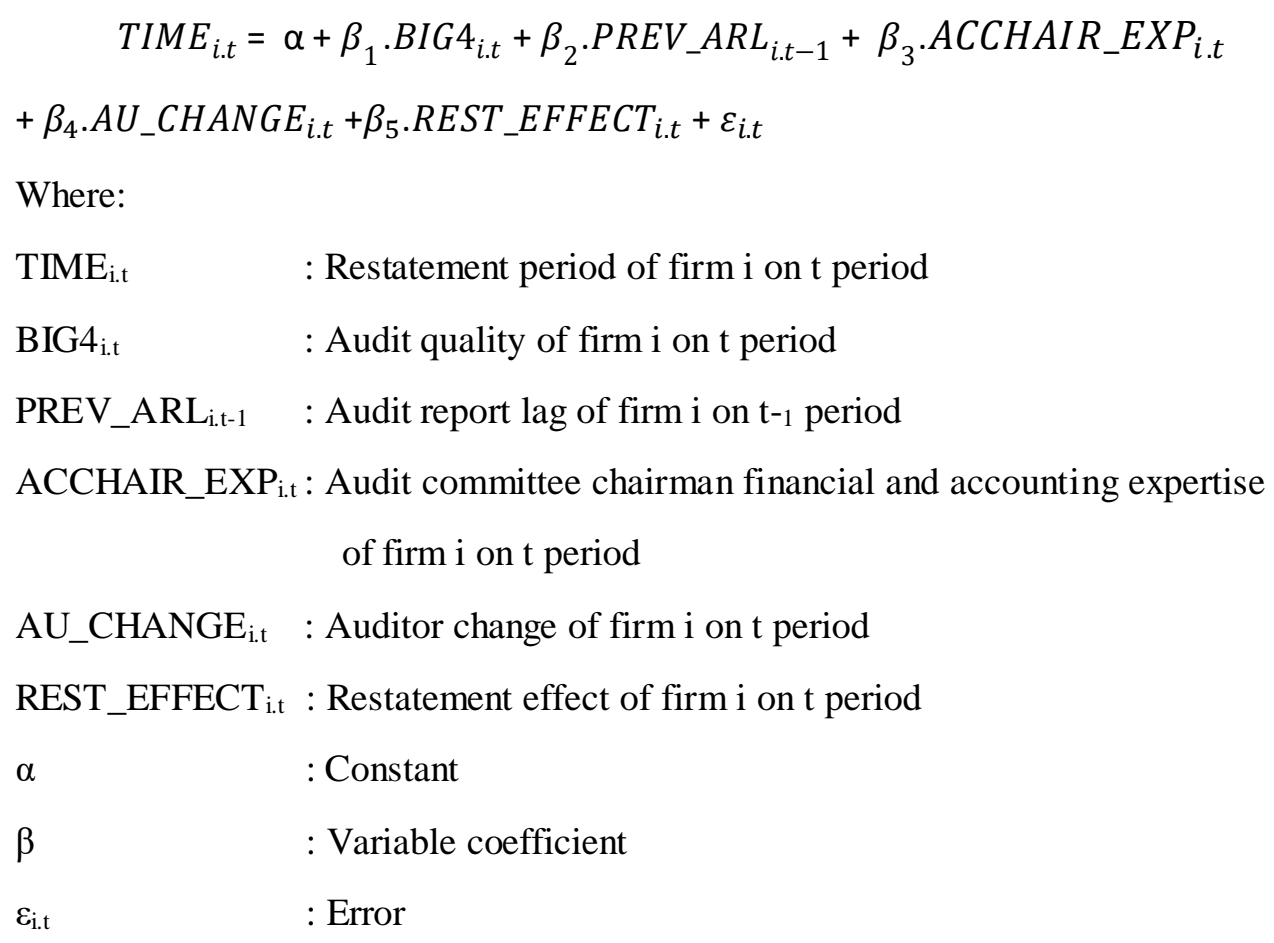$$
T I M E_{i . t}=\alpha+\beta_{1} \cdot B I G 4_{i . t}+\beta_{2} . P R E V_{-} A R L_{i . t-1}+\beta_{3} \cdot A C C H A I R \_E X P_{i . t}
$$$$
+\beta_{4} \cdot A U_{-} C H A N G E_{i . t}+\beta_{5} \cdot R E S T_{-} E F F E C T_{i . t}+\varepsilon_{i . t}
$$

Where:

TIME $_{\text {i.t }} \quad:$ Restatement period of firm $\mathrm{i}$ on $\mathrm{t}$ period

BIG4 $4_{\text {i.t }} \quad$ : Audit quality of firm i on t period

PREV_ARLi.t-1 : Audit report lag of firm i on t-1 period

ACCHAIR_EXP $\mathrm{i}_{\mathrm{i} . \mathrm{t}}$ : Audit committee chairman financial and accounting expertise of firm $\mathrm{i}$ on $\mathrm{t}$ period

AU_CHANGE $\mathrm{i}_{\mathrm{i} . \mathrm{t}}$ : Auditor change of firm i on $\mathrm{t}$ period

REST_EFFECT $T_{\text {i.t }}$ : Restatement effect of firm i on t period

$\alpha$

: Constant

$\beta \quad$ : Variable coefficient

$\varepsilon_{\text {i.t }} \quad:$ Error

\subsection{Research Variable Operationalization}

\subsubsection{Restatement Period}

The dependent variable in this study is TIME, which measures the restatement period. TIME is defined by the number of days passed between the first publication date of the financial statement and the discovery of the need for a restatement and the restated financial statement's issuance (Schmidt and Wilkins, 2013).

\subsubsection{Audit Quality}

Big-Four Public Accounting Firms, as an independent variable, is consistently associated in explaining audit quality. Francis and Yu (2009) documented that Big-Four Public Accounting Firms indicate higher audit quality than smaller public accounting firms. The supporting argument is that Big-Four Public Accounting Firms have a more 
significant number of trained and experienced personnel. BIG4 is a dummy variable; thus, code 1 is given if the auditor of the restating company is a Big-Four Public Accounting Firm, and 0 otherwise.

\subsubsection{Audit Report Lag}

The independent variable, audit report lag (PREV_ARL), interprets delay of audit report issuance a year before the restatement. PREV_ARL is determined from the length of time between a firm's fiscal year-end and the audit report's signing date (Steward and Caimey, 2019), which occurs a year before the restatement.

\subsubsection{Audit Committee Characteristic}

This study employs a single proxy to represent the audit committee characteristic, i.e., audit committee chairman financial and accounting expertise (ACCHAIR_EXP). This measurement was also utilized by Schmidt and Wilkins (2013). ACCHAIR_EXP is an indicator variable that takes a value of 1 if the audit committee chairman is a financial and accounting expert and 0 otherwise.

\subsubsection{Controlling Variables}

This study also includes control variables at the auditor level and company level, as follows:

\section{(i) Auditor Change}

Auditor change (AU_CHANGE) consists of both mandatory and voluntary changes (Susan and Trisnawati, 2013). Auditor change is a dummy variable set equal to 1 if an auditor changes in the observation period and 0 otherwise.

(ii) Restatement Effect

The restatement effect is calculated by the difference of the firm's earnings before and after restatement occurs. This variable is obtained from the absolute value of the natural $\log$ of the cumulative restatement effect.

\section{RESULTS AND DISCUSSION}

\subsection{Research Data}

Objects included in this study are listed companies on Indonesia Stock Exchange from 2016 to 2018, collected with the purposive sampling method. The data involved 
in this study were gathered from financial statements and annual reports published by related firms, obtained through IDX's official website and firm's website. With criteria applied in Chapter 3 as the primary basis, 153 firms were collected from the year 2016 to 2018. The sampling procedure is presented in Table 1, and total observations in Table 2.

According to annual financial statements from 2016 to 2018, there are 150 firms having restatement and revisions. However, only 111 of them qualify the sample criteria. Among these 111 firms, 18 are set off by more than one trigger to do financial restatements. Prior studies (Anderson and Yohn, 2002; and Dewi, 2014) treat these firms with separate observations. Therefore, there are 85 samples obtained for the year 2016, 50 samples for the year 2017, and 48 samples for the year 2018, which results in 153 observation data.

As from total companies listed in BEI from 2016 to 2018, only 111 entities meet the sampling criteria; thus, the total observation in this study is 153 data. However, to satisfy the classic assumption tests requirements, a final total of 148 data is used.

Table 1.

Sampling Procedures

\begin{tabular}{lc}
\hline \multicolumn{1}{c}{ Explanation } & Number of Firms \\
\hline $\begin{array}{l}\text { Listed companies on Indonesia Stock Exchange from 2016, } \\
\text { 2017, and } 2018 \text { period }\end{array}$ & 652 \\
Companies with no restatement from the year 2016 to 2018 & $(502)$ \\
Companies do not present the financial statement in Rupiah \\
(IDR) \\
$\begin{array}{l}\text { Companies do not disclose the required information in this } \\
\text { study }\end{array}$ \\
\hline Total firms as sample
\end{tabular}

Source: Results of data processing (2019) 
Table 2.

Total Observation

\section{Number of Observation}

Total research data 153 data

Data affected with treatment effect

Total observation data

148

Source: Results of data processing (2019)

Table 3.

Distribution of Restatement Reason

$\begin{array}{lc}\text { Category } & \text { Number of Incidents } \\ \text { TIME }\end{array} \%$ BIG4

Changes in accounting standards:
a. PSAK 69
24
358,17
70,83
b. PSAK 16
12
360,25
66,67
c. ISAK 31
7
364,43
14,29
Account reclassification
37
352,89
21,62
Business combination
24
309,13
37,5
Discontinued operation
7
367,57
42,86
Deferred tax adjustment
4
408,25
25
Stock split
4
356,25
25
Others
34
330,38
38,26
TOTAL
153

Source: Results of data processing (2019)

According to the sample's distribution in Table 3, this study classified restatement types based on its reason. Information regarding the average restatement period and percentage of firms engaged Big-Four Public Accounting Firms as the external auditor is also shown in the table. 
Samples were divided into six main categories, i.e., restatement caused by changes in Accounting Standard, account reclassifications, business combinations, discontinued operations, deferred tax adjustments, and stock split.

There were a total of 153 restatement events from 111 sample entities involved in this study.

Most firms restate their financial statements due to changes in accounting standards and account reclassification. Twenty-eight percent of total samples' restatement reason is due to the changes in accounting standard, while twenty-four percent other is caused by account reclassification. Moreover, the category with the most extended restatement period is deferred tax adjustments, and the category with the shortest period is a business combination.

Every company has various considerations to restate financial statements. While the public believes that restatement is a bad signal, it is not valid for most reasons. For instance, restatement due to accounting changes is a form of compliance with established regulations regarding financial statement presentation. As a result, litigation risks caused by the violation can be avoided. Most clients that adopt new accounting standards utilize Big-Four Public Accounting Firms audit by 50,6\%. Since companies consider compliance to be a crucial aspect, the willingness to pay higher to ensure that accounting standards have been precisely applied and assure the quality of information is relevant and reliable, which enhances financial statement users' trust.

A similar condition applies to account reclassification as well. Only four out of 37 companies show either a rise or reduction in earnings, whereas the others have zero effect. Accordingly, account reclassification is not a form of earnings management; it is done to raise the relevance between an account and its related balance. Thus, it is fair to state that restatement brings a positive impact on companies.

Table 3 does not reveal any trends associated between the restatement period and Big-Four Public Accounting Firms. This finding is due to the percentage of observations that Big-Four Public Accounting Firms audit for the longest and shortest restatement period does not show a significant difference. 


\subsection{Research Results}

\subsubsection{Descriptive Statistics Analysis}

Table 4.

Statistic Descriptive Analysis Results

\begin{tabular}{lcccc}
\hline Variable & Mean & Standard Deviation & $25 \%$ & $75 \%$ \\
\hline TIME & 354,39 & 49,52 & 117 & 475 \\
BIG4 & 0,41 & 0,49 & 0 & 1 \\
ACCHAIR_EXP & 0,64 & 0,48 & 0 & 1 \\
PREV_ARL & 77,11 & 20,11 & 12 & 173 \\
AU_CHANGE & 0,12 & 0,33 & 0 & 1 \\
REST_EFFECT & 5,23 & 5,04 & 0 & 11,99
\end{tabular}

Source: Results of data processing (2019)

Referring to Table 4, the result of descriptive statistics on restatement period (TIME) shows the mean value of 354,39 ; standard deviation value of 49,52 ; the minimum value of 117; and the maximum value of 475 . This finding concludes that the average restatement period is 354 to 355 days, with the shortest period of 117 days and the longest period of 475 days. Thirty observations' restatements period is below the average, while 118 others are above the average.

Audit quality (BIG4) shows the mean value of 0,41 ; standard deviation value of 0,49 ; the minimum value of 0 ; and the maximum value of 1 . This finding explains that the number of firms engaged in Big-Four Public Accounting Firms as external auditors are lower, i.e., only 61 firms, while non-Big-Four Public Accounting Firms audit 87 others.

The audit committee's characteristic (ACCHAIR_EXP) shows the mean value of 0,64 , standard deviation value of 0,48 , the minimum value of 0 , and the maximum value of 1 . This finding confirms that more companies have financial/accounting expertise as the audit committee chairman, with 95 companies. In comparison, the 53 other companies' audit committee chairman is not a financial/accounting expertise. 
Audit report lag (PREV_ARL) shows the mean value of 77,11; standard deviation value of 20,11; the minimum value of 12 ; and the maximum value of 173 . There are 91 firms below the average and 51 above the average. The company with the longest audit report lag with a length of 173 days is Central Proteina Prima Tbk, and the shortest audit report lag with a length of 12 days is BFI Finance Indonesia.

Table 5.

Pearson Correlation Result

\begin{tabular}{|c|c|c|c|c|c|c|}
\hline Variable & TIME & BIG4 & $\begin{array}{c}\text { AC } \\
\text { CHAIR_- } \\
\text { EXP }\end{array}$ & $\begin{array}{c}\text { PREV }_{-} \\
\text {ARL }\end{array}$ & $\begin{array}{c}\mathrm{AU}_{-} \\
\mathrm{CHANGE}\end{array}$ & $\begin{array}{l}\text { REST }_{-} \\
\text {EFFECT }\end{array}$ \\
\hline TIME & 1,000 & & & & & \\
\hline BIG4 & 0,143 & 1,000 & & & & \\
\hline ACCHAIR_EXP & $-0,140$ & 0,100 & 1,000 & & & \\
\hline PREV_ARL & $-0,241$ & $-0,037$ & 0,058 & 1,000 & & \\
\hline AU_CHANGE & 0,186 & $-0,139$ & $-0,067$ & $-0,177$ & 1,000 & \\
\hline REST_EFFECT & 0,173 & 0,070 & 0,079 & 0,178 & $-0,176$ & 1,000 \\
\hline
\end{tabular}

Source: Results of data processing (2019)

Auditor change (AU_CHANGE) shows the mean value of 0,12; standard deviation value of 0,33 ; the minimum value of 0 ; and the maximum value of 1 . Thus, only a small number of firms have auditor changes, i.e., 18 of 130 firms.

Restatement effect (REST_EFFECT) shows the mean value of 5,23; standard deviation value of 5,04; the minimum value of 0 ; and the maximum value of 11,99. There are two firms with maximum restatement effect, while the 70 others have a minimum value of restatement effect (zero effect). The firm with the lowest restatement effect after zero is Prasidha Aneka Niaga Tbk.

\subsubsection{Correlation Analysis}

Table 5 indicates no correlation between the independent and dependent variables. The initial indication through correlation analysis is BIG4, ACCHAIR_EXP, 
PREV_ARL, AU_CHANGE, and REST_EFFECT, a weak correlation with the restatement period.

\subsubsection{Multiple Regression Analysis}

This section presents the results associated with the hypothesis. The results are obtained by conducting several tests, including Pearson correlation, regression, and Ttest.

Table 6.

Hypothesis Testing Result

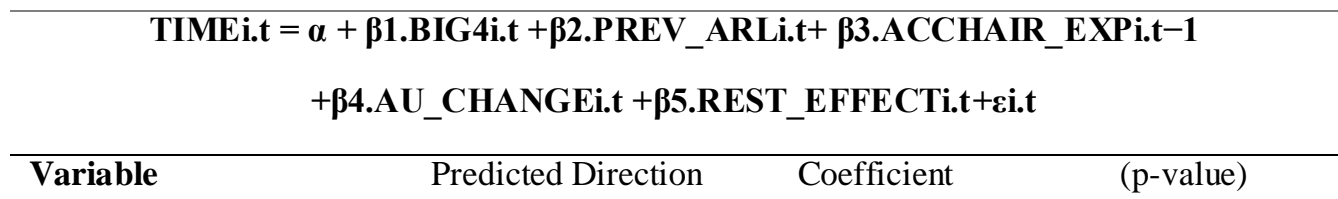

Dependent variable:

TIME

Independent variables:

BIG4 $\left(\mathbf{H}_{1}\right) \quad-\quad-16,001 \quad(0,021)^{*}$

PREV_ARL $\left(\mathbf{H}_{2}\right) \quad-\quad-0,579 \quad(0,002)^{* *}$

ACCHAIR_EXP $\left(\mathbf{H}_{3}\right) \quad-\quad-15,286 \quad(0,023)^{*}$

Controlling variables:

$\begin{array}{lccc}\text { AU_CHANGE } & ? & 30,368 & (0,006)^{* *} \\ \text { REST_EFFECT } & ? & 2,466 & (0,001)^{* *}\end{array}$

$\mathrm{N}=148$

$\mathrm{F} \quad \mathbf{= 6 , 2 7 3}$

SigF $=0,000$

Adjusted R Square $=0,152$

*Significant on $p$-value $<0,05$

**Significant on $p$-value $<0.01$

Source: Results of data processing (2019) 
Table 6 shows that the coefficient is 0,000 , which is statistically significant $(\mathrm{p}<$ 0.05 ). It indicates that the independent variables (audit quality, audit committee characteristic, and audit report lag) significantly influence the dependent variables (restatement).

Table 6 also shows that the adjusted R-Square indicates that 15,2 percent restatement is reflected by the independent variables included in the model. In comparison, 84,4 percent are influenced by various variables not included in this research model.

Table 6 presents the pairwise correlations between independent variables and dependent variables by comparing the results with a significant level. If the results occur below the significant level $(\mathrm{p}<0,05)$, it indicates that the dependent variables significantly influence the independent variables. The direction could be identified through the positive or negative symbol in the coefficient.

\subsection{Hypothesis Testing Discussion}

\subsubsection{The Effect of Audit Quality towards Restatement Period}

Based on the conducted regression analysis, Audit Quality (BIG4) shows that the coefficient is 0.021 , which is below the significant level $(\mathrm{p}<0,05)$. It indicates that Audit Quality (BIG4) is positive and statistically significant. H1 predicts that Audit Quality (BIG4) will shorten the restatement period (TIME). However, as indicated earlier, the coefficient does occur below the significant level, but it shows a positive correlation. The positive correlation explains that the Audit Quality (BIG4) precisely extends the restatement period (TIME). Thus, our findings do not adequately support H1.

In this research, Audit Quality (BIG4) is represented by the Big-Four public accounting firms. The reason is that the Big-Four public accounting firms are believed to have adequate capabilities to conduct audit procedures rather than the non-Big-Four public accounting firms, which reflects that the Big-Four public accounting firms have sufficient competence in order to respond to various issues associated with the restatement. However, due to the higher quality of audits conducted by the Big-Four 
public accounting firms, there could be a possibility that the auditors from Big-Four would conduct the audit with higher due care as well, especially the issues associated with balances and particular items in financial statements. On the other hand, this research also includes the controlled variables: the auditor change (AU_CHANGE) and restatement effect (REST_EFFECT). It identifies the likelihood of firms to change their auditor, which extends the period of restatement since initial engagement would likely increase the inherent risk. The restatement effect (REST_EFFECT) variable indicates that the higher the effect, the more it would increase the likelihood of the auditor to conduct the audit procedures more thoroughly. Thus, Audit Quality (BIG4) would extend the restatement period.

Another factor contributing to the result shows that 59 percent of the majority of the sample used in this research utilizes the non-Big-Four Public Accounting Firms as their auditor. This condition differs from the prior studies in several countries whose auditors are from the Big-Four Public Accounting Firms.

Our findings align with the prior research by Rowe (2018), which defines that Audit Quality (BIG4) will extend the restatement period. Nevertheless, it is contradicted with prior research conducted by Schmidt and Wilkins (2013), Francis et al. (2013), Zhizhong et al. (2011), Jiang et al. (2015), Lobo (2013), and Kusuma and Rohman (2014) which present that Audit Quality (BIG4) will reduce the restatement period.

The auditor's ability to mitigate misstatements is a function of the auditor's ability to answer material misstatements and to adjust or report them (DeAngelo, 1981). However, the auditor size (BIG4) results do not identify whether the findings are driven by detection ability or reporting incentives because both are correlated with auditor size. This is due to the lack of empirical evidence related to proxies for these constructs, such as having hours spent on audits (Caramanis and Lennox, 2008) and auditing industry expertise (Krishnan 2003).

\subsubsection{The Effect of Audit Report Lag towards Restatement Period}

Based on the regression, Audit Report Lag (PREV_ARL) shows that the coefficient is below the significant level $(p<0,05)$ and is negative. The coefficient 
estimates of 0,002 reveal that the longer the Audit Report Lag (PREV_ARL) could result in a shortened restatement period. This finding supports our third hypothesis, in which the lengthy Audit Report Lag (PREV_ARL) could reduce the length of the restatement period.

In this research, Audit Report Lag (PREV_ARL) is defined by the sum of days started from the firm's last fiscal year-end date until the date when the audit report is published (Stewart and Caimey, 2019). Our research uses the audit report lag from the prior year to indicate whether it will reduce or increase the period of restatement in the next year. If the prior year's audit report lag takes a more lengthened period, it indicates that Public Accounting Firms require a longer period to perform the audit procedures before publishing it. Sufficient time given to the audit committee can assure the auditor conducts the audit procedures with high professional due care. The financial report published will likely meet the rules and standards applied. The visible effect will also affect future auditing. There will be a decrease in the likelihood of financial misstatement and a shortened restatement period in the following year.

The result is aligned with the prior studies by Blankley et al. (2015) and Wei et al. (2017), which indicated that Audit Report Lag influenced the length of the restatement period in the following year. Other literature recognizes the critical role of entities other than auditors, such as actuaries, venture capitalists, or underwriters, that are directly involved in the financial reporting process or influence financial reporting incentives. Examples of such studies include Gaver and Paterson (2001), Morsfield and Tan (2006), Jo et al. (2007), and Bushee (1998), which can also influence the length of the restatement period.

\subsubsection{The Effect of Audit Committee Characteristic towards Restatement Period}

The regression analysis shows that the audit committee characteristic (ACCHAIR_EXP) is negative with 0,025 as the coefficient, which is still below the significant level $(\mathrm{p}<0,05)$. This finding implies that the audit committee characteristic (ACCHAIR_EXP) negatively influences reducing the restatement period. Therefore, our second hypothesis $(\mathrm{H} 2)$, which predicts that the audit committee characteristic 
(ACCHAIR_EXP) could reduce the length of the restatement period, is proven and is supported by the finding above.

The audit committee characteristic (ACCHAIR_EXP) is indicated by the audit committee chairman's expertise in finance or accounting. It is a general belief that the audit committee chairman with expertise in the related field is more likely to apply the adequate experiences and competence they have. As a result, related discussion and detection concerning balances and several accounting items issues could be conducted effectively and efficiently. The audit committee chairman's commitment to competence indicates that the firm has adequate internal control, specifically in the environment control element. This research also includes two additional control measures: auditor change (AU_CHANGE) and restatement effect (REST_EFFECT).

The audit committee whose expertise is in financial and accounting will shorten the time needed in accommodating auditor change conducted by the firms. Besides, this expertise will be a great help to evaluate the impact of restatement holistically. In conclusion, the audit committee characteristic (ACCHAIR_EXP) shorten the period of the restatement.

In conclusion, the result of this research is similar to the prior study conducted by Schmidt and Wilkins (2013), which proved that the audit committee chairman's expertise in financial and accounting is negatively associated with the restatement period. McDaniel et al. (2002) also find that financial experts help audit committees monitor more crucial financial reporting issues.

\section{CONCLUSION, IMPLICATION, LIMITATION}

\subsection{Conclusion}

This research aims to discover if internal and external supervision correlates toward the period of the restatement. The audit committee's role is to supervise internally and is considered an expert related to financial and accounting. It assumes that the audit committee with adequate knowledge and experience in the related field will result in a shortened restatement period because they have skills and therefore conduct the auditing in more due diligence supervision. In contrast, the external auditor 
will be in charge of supervising externally. The Big-Four Public Accounting Firm is defined as the external auditor in this research. This assumption is made because BigFour Public Accounting Firms possess more sufficient capabilities and knowledge related to clients' business processes. With these considerations, Big-Four Public Accounting Firms, as the external auditor, is more likely to hold firm and implement the professional due care competently when performing their duty in the supervision process resulting in longer audit report lag. The lengthy audit report lag will reduce the possibility of financial misstatement in the future, and if any, the time needed will be shortened. Thus, the higher quality of external auditors' external supervision, the shorter the restatement period takes.

Obtained results show that audit quality is positively associated with the restatement period. Therefore, the first hypothesis proposed in this research is rejected. On the other hand, audit report lag is negatively associated with the restatement, which consistently shows that the longer the audit report lag, the shorter the restatement period. The last finding indicates that the audit committee characteristic is negatively associated with the restatement period. In conclusion, this research reveals that audit report lag and audit committee characteristics will likely reduce the length of the restatement period, while the audit quality, in contrast, will extend the restatement period.

\subsection{Implication and Limitation}

The results of this study include some limitations. The first limitation is the absence of specific regulations related to the length of the restatement period. This absence becomes one reason why many firms in Indonesia mostly publish their financial restatement in conjunction with the publication of the following year's financial statement. Meanwhile, firms in other countries publish their financial restatement, mostly in the interim period. Furthermore, this study utilizes only one proxy for every variable with a relatively short period of observation which is only three years. This study also does not classify the sample using inclusion criteria such as those 
who conduct restatements due to accounting errors or changes in accounting standards, resulting in a less specified objective.

Future research may use the sample of firms with restatement due to unusual causes such as fraud, an inaccurate process in acquisition and merger, and related factors. Future research may also utilize various alternatives for the proxy Accounting Firms and extend the observation period to obtain more ideal results. Besides, future research may also extend the population not only on the Indonesia Stock Exchange but also on the firms listed on the Foreign Stock Exchange.

\section{References}

Ali, M. M., Besar, S. S. N. T., dan Mastiki, N. M. (2017). Audit Committee Characteristics, Risk Management Committee, and Financial Restatements. Advanced Science Letters, 23, 287-291. doi: 10.1166/asl.2017.7160

Anderson, K. L., \& Yohn, T. L. (2002). The Effect of 10K Restatements on Firm Value, Information Asymmetries, and Investors' Reliance on Earnings. SSRN Electronic Journal. doi:10.2139/ssrn.332380

Aprillia, Ekka. (2013). Analisis Faktor-Faktor yang Mempengaruhi Auditor Switching. Accounting Analysis Journal, 2, 199-2017. doi:10.15294/aaj.v2i2.1577

Arens, A.A., Elder, R. J., Beasley, M. S., \& Hogan, C. E. (2017). Auditing and Assurance Services. England: Pearson Education Limited.

Bedard, J. C., \& Johnstone, K. M. (2004). Earnings Manipulation Risk, Corporate Governance Risk, and Auditors' Planning and Pricing Decisions. The Accounting Review, 79(2), 277-304. doi: 10.2308/accr.2004.79.2.277

Blankley, A. I., Hurtt, D. N., \& Macgregor, J. E. (2015). Are Lengthy Audit Report Lags a Warning Signal? Current Issues In Auditing, 9(2), 19-28. doi: 10.2308/ciia-51215

Bushee, B. (1998). The Influence of Institutional Investors In Myopic R\&D Investment Behavior. The Accounting Review 73, 305-333

Caramanis, C., Lennox, C. (2008). Audit Effort and Earnings Management. Journal of Accounting and Economics 45, 116-138. 
Carcello, J. V., Neal, T. L, Palmrose, Z. V., \& Scholz, S. (2011). CEO Involvement in Selecting Board Members, Audit Committee Effectiveness, and Restatements. Contemporary Accounting Research, 28(2), 296-430. doi: 10.1111/j.191-3846.2010.01052.x

Cohen, J. R., Hoitash, U., Krishnamoorthy, G., \& Wright, A. M. (2013). The Effect of Audit Committee Industry Expertise on Monitoring the Financial Reporting Process. The Accounting Review, 89(1), 243-273. doi:10.2308/accr-50585

DeAngelo, Linda Elizabeth. (1981). Auditor Size and Audit Quality. Journal of Accounting and Economics, 3, 183-199. https://doi.org/10.1016/0165-4101(81)90002-1

Dewi, D. N. (2014). Positive Reaction to Accounting Restatement: The Episode of Reasons and Earning Changes. Jurnal Ilmiah ESAI, 8(3).

DeZoort, F. T., \& Salterio, S.E. (2001). The Effect of Corporate Governance Experience and Financial- Reporting and Audit Knowledge on Audit Committee Members' Judgments. AUDITING: A Journal of Practice \& Theory, 20(2), 31-47. doi:10.2308/aud.2001.20.2.31

Étienne, J. (2010). Compliance Theory: A Literature Review. Revue française de science politique, 60, 493-517. doi: 10.3917/rfsp.603.0493

Francis, J. R., \& Yu, M. D. (2009). Big 4 Office Size and Audit Quality. The Accounting Review, 84(5), 1521-1552. doi:10.2308/accr.2009.84.5.1521

Francis, J. R., Michas, P. N., \& Yu, M. D. (2013). Office Size of Big 4 Auditors and Client Restatements. Contemporary Accounting Research, 30 (4), 1626-1661. doi:10.1111/1911-3846.12011

Gaver, J., Paterson, J. (2001). The Association Between External Monitoring and Earnings Management in The Property-Casualty Insurance Industry. Journal of Accounting Research 39, 269-282.

Hasnan, S., \& Hussain, A. R. M. (2015). Factors Associated with Financial Restatements: Evidence from Malaysia. Jurnal Pengurusan, 44, 105-116. doi: 10.17576/pengurusan-2015-44-10

Jensen, M. C., \& Meckling, W. H. (1976). Theory of the Firm: Managerial Behavior, Agency Costs, and Ownership Structure. Journal of Financial Economics, 3, 305-360. doi:10.1016/0304- 405X(76)90026-X

Jiang, H., Habib, A., \& Zhou, D. (2015). Accounting Restatements and Audit Quality in China. Advances in Accounting, Incorporating Advances in International Accounting, 31, 126-135. https://doi.org/10.1016/j.adiac.2015.03.014 
Jo, H., Kim, Y., Park, M. (2007). Underwriter Choice and Earnings Management: Evidence From Seasoned Equity Offerings. Review of Accounting Studies 12, 23-59.

Krishnan, G. (2003). Does Big 6 Auditor Industry Expertise Constrain Earnings Management? Accounting Horizons 17, 1-16.

Krishnan, G., \& Visvanathan, G. (2009). Do Auditors Price Audit Committee's Expertise? The Case of Accounting versus Nonaccounting Financial Experts. Journal of Accounting, Auditing \& Finance, 24(1), 115-144. doi:10.1177/0148558x0902400107

Kusuma, I. B., \& Rohman, A. (2014). Analisis Mekanisme Corporate Governance terhadap Probabilitas Terjadinya Earnings Restatement. Diponegoro Journal of Accounting, 3 (2), 1-15. Retrieved from http://ejournal-s1.undip.ac.id/index.php/accounting

Lobo, J.G., \& Zhao, Y. (2013). Relation Between Audit Effort and Financial Report Misstaments: Evidence from Quarterly and Annual Restatements. The Accounting Review, 88, 1385-1412. https://doi.org/10.2308/accr-50440

Lunenburg, F.C. (2012). Compliance Theory and Organizational Effectiveness. International Journal of Scholarly Academic Intellectual Diversity, 14(1), 1-4.

Mao, Yazhi. (2018). Financial Restatement Research Literature Review. Modern Economy, 9, 2092-2103. doi:10.4236/me.2018.912130

McDaniel, L., Martin, R., Maines, L. (2002). Evaluating Financial Reporting Quality: The Effects of Financial Expertise vs. Financial Literacy. The Accounting Review 77 (Suppl.), 139-167.

Morsfield, S., Tan, C. (2006). Do Venture Capitalists Influence The Decision to Manage Earnings in Initial Public Offerings? The Accounting Review 81, 1119-1150.

Otoritas Jasa Keuangan. (2016). Peraturan Otoritas Jasa Keuangan Nomor 29/POJK.04/2016 tentang Laporan Tahunan Emiten atau Perusahaan Publik. Jakarta: Otoritas Jasa Keuangan Republik Indonesia.

Pertami, Yuli Surya Fauzia. (2016). Pengaruh Restatement Laporan Keuangan terhadap Abnormal Return. Sistem Infromasi, Keuangan, Auditing, dan Perpajakan, 1 (1), 2935. doi:10.32897/jsikap.v1i1.44

Rowe, S.P., \& Sivadasan, P. (2018). Higher Audit Quality and Higher Restatememt Rates: An Examination of Big Four Auditee Restatements. Retrieved from http://dx.doi.org/10.2139/ssrn.3235756

Schimdt, J., \& Wilkins, M.S. (2013). Bringing Darkness to Light: The Influence of Auditor Quality and Audit Committee Expertise on the Timeliness of Financial Statement 
Restatement Disclosures. Auditing: A Journal of Practice and Theory, 32, 221-244. doi: 10.2308/ajpt-50307

Shin, H., Xu, R. Z., Lacina, M., \& Zhang, J. (2014). Audit Committee Expertise and Early Accounting Error Detection: Evidence from Financial Restatements. Journal of Forensic \& Investigative Accounting, 6(1), 181-221. Retrieved from http://web.nacva.com/JFIA/Issues/JFIA-2014-1_7.pdf

Stewart, E. G., \& Cairney, T. D. (2019). Audit Report Lag and Client Industry Homogeneity. Managerial Accounting Journal, 34(8), 1008-1028. doi: 10.1108/MAJ-07-2018-1931

Susan dan Trisnawati, E. (2011). Faktor-Faktor yang Mempengaruhi Perusahaan Melakukan Auditor Switch. Jurnal Bisnis dan Akuntansi, 13(2), 131-144. https://doi.org/10.34208/jba.v13i2.132

United States Government Accountability Office. (2006). Financial Restatements. Retrieved from https://www.gao.gov/new.items/d06678.pdf

Wei, H. N., Cheng, W., \& Zhao, Y. (2017). Empirical Study on Phenomenon of Audit Report Lag and Financial Restatement in Chinese Listing Corporation. 2017 International Conference on Service Systems and Service Management. doi:10.1109/icsssm.2017.7996227

Zhizhong, H., Juan, Z., Yanzhi, S., \& Wenli, X. (2011). Does Corporate Governance Affect Restatement of Financial Reporting? Evidence from China. Nankai Business Review International, 2, 289-302. doi: 10.1108/20408741111155307 